\title{
Production of IgY polyclonal antibody against diphtheria toxin and evaluation of its neutralization effect by Vero cell assay
}

\author{
Morteza Rezaeifard ${ }^{1,2}$, Roya Solhi ${ }^{1,2}$, Mohammad Mohammadi $^{3}$, Ebrahim Abbasi ${ }^{4}$ and Mahdi Aminian ${ }^{1,5^{*}}$ (D)
}

\begin{abstract}
Background: Diphtheria is a bacterial disease which is caused by Corynebacterium diphtheriae. The symptoms are due to the diphtheria toxin produced by the bacteria. Antibiotic therapy and the use of diphtheria antitoxin is a recommended strategy to control diphtheria. Although mammalian antibodies are used to treat patients, IgY antibody has advantages over mammalian ones, including cost-effectiveness and production through non-invasive means. Moreover, in contrast to mammalian antibodies, IgY does not bind to the rheumatoid factor and does not activate the complement system. The objective of this study was to evaluate the in vitro neutralizing effect of $\lg Y$ against diphtheria toxin.

Results: Anti-DT IgY was produced by immunization of the laying white leghorn chickens. Indirect enzyme-linked immunosorbent assay revealed successful immunization of the animals, and the $\lg Y$ was purified with a purity of $93 \%$ via polyethylene glycol precipitation method. The neutralizing activity of the purified IgY was evaluated by Vero cell viability assay. This assay confirmed that $1.95 \mu \mathrm{g}(8.6 \mu \mathrm{g} / \mathrm{ml}$ of culture medium) of anti-DT IgY would neutralize 10 fold of cytotoxic dose $99 \%$ of DT, which was $0.3 \mathrm{ng}(1.33 \mathrm{ng} / \mathrm{ml}$ of culture medium).
\end{abstract}

Conclusion: This anti-DT IgY may be applicable for diphtheria treatment and quality controls in vaccine production.

Keywords: Diphtheria toxin, IgY, Purification, Vero cell

\section{Background}

Diphtheria is an infectious disease caused by Corynebacterium diphtheria. It is often localized in the upper respiratory tract, which produces a thick and grey pseudomembrane. Diphtheria leads to difficulty in breathing, swallowing, myocardial complications, and finally, brain anoxia which can cause death [1]. The bacteria secrete a protein called diphtheria toxin (DT), which is about $62 \mathrm{kDa}$ consists of 535 amino acids. Diphtheria toxin plays a principal role in diphtheria

\footnotetext{
* Correspondence: amminian@tums.ac.ir

'Department of Clinical Biochemistry, School of Medicine, Tehran University of Medical Sciences, Poursina Street, Keshavarz Boulevard, Tehran, Iran

${ }^{5}$ Recombinant Vaccine Research Center, Tehran University of Medical Sciences, Tehran, Iran

Full list of author information is available at the end of the article
}

pathogenesis in which the protein synthesis is arrested by ADP ribosylation of elongation factor 2 [2].

Because of the high rate of immunization, diphtheria incidence has declined dramatically. However, due to low vaccination coverage in some countries, loss of vaccine-induced immunity over time, increases in international travels, and the emergence of new biotypes, diphtheria has not been eradicated in the world [3]. According to World Health Organization, more than 7000 cases of diphtheria were reported worldwide in 2016 [4]. Moreover, fatal cases have also occurred over the last decade among developing and developed countries throughout the world [5].

The recommended strategy for controlling diphtheria infection is antibiotic therapy in combination with diphtheria antitoxin (DAT) [6]. Antibiotic treatment after 
manifestation of the symptoms may not be effective enough. Hence, Finding an appropriate antibiotic for the treatment of multi-drug resistant strains of the bacteria is a considerable problem [7]. For a long time, equinederived DAT was applied to provide patients with passive immunity. Serum sickness associated with horsederived DAT is a drawback of its efficacy $[6,8]$. Antibodies from immunized human individuals are also used for the treatment of the patients. However, in addition to the disease transfer problem, the supply of human derived-serum is limited, and the production of DAT from the immunized population is not cost-effective [5, 9]. The risk of serum-borne diseases, hypersensitivity, the growing needs, and extremely limited resources altogether provide an incentive to find more efficient alternatives for current diphtheria antitoxins [10].

IgY antibodies have received plenty of attention due to several advantages, including low cost and non-invasive means of production compared to mammalian antibodies $[11,12]$. Moreover, IgY does not react with mammalian complement and rheumatoid factors (RF) [13, 14]. RF is an autoantibody that binds to the Fc region of mammalian IgG, causing interference in many immunoassays [15]. In contrast to mammalian antibodies, IgY does not bind to the cell surface Fc receptors and provides higher stability against environmental conditions such as $\mathrm{pH}$ and temperature $[12,16]$. Interestingly, several researchers have demonstrated that IgY antibodies can be used for therapeutic applications, especially in infectious diseases and toxin neutralization [16-20].

Nevertheless, to the best of our knowledge, there has been no report on the efficacy of IgY polyclonal antibody against diphtheria toxin. This study aims to produce anti-DT IgY and evaluate its neutralization effect against cell toxicity of diphtheria toxin.

\section{Results}

\section{ELISA titration of anti-DTx IgY}

Levels of specific anti-diphtheria toxoid IgY were measured by ELISA (Fig. 1). Increases in specific IgY titers were observed after each injection and reached the highest amounts after the fourth immunization. The IgY titers remained relatively high after the last booster for 5 months, with some variations. There was no increase in the titer of specific IgY in the control group. After the second immunization, eggs were collected daily, and the yolks were pooled for the subsequent purification.

\section{$\lg \mathrm{Y}$ purification}

Purification of IgY from egg yolks performed by polyethylene glycol (PEG) precipitation method and the sodium dodecyl sulfate-polyacrylamide gel electrophoresis (SDS-PAGE) results are demonstrated in Fig. 2. The ImageJ analysis verified a purity of about $93 \%$. Purified IgY showed a protein band with the apparent molecular weight of $180 \mathrm{kDa}$ under non-reducing conditions.



Fig. 1 Titration curve of IgY production. A group of two chickens was immunized with $0.1 \mathrm{mg}$ of diphtheria toxoid on days of $0,18,43$, and 62 . The level of IgY was determined by indirect ELISA using diphtheria toxoid. Each experiment was performed in two replicates, and the mean \pm SD of samples was represented. All Data are normalized against the mean value of the control group injected by PBS and adjuvant 


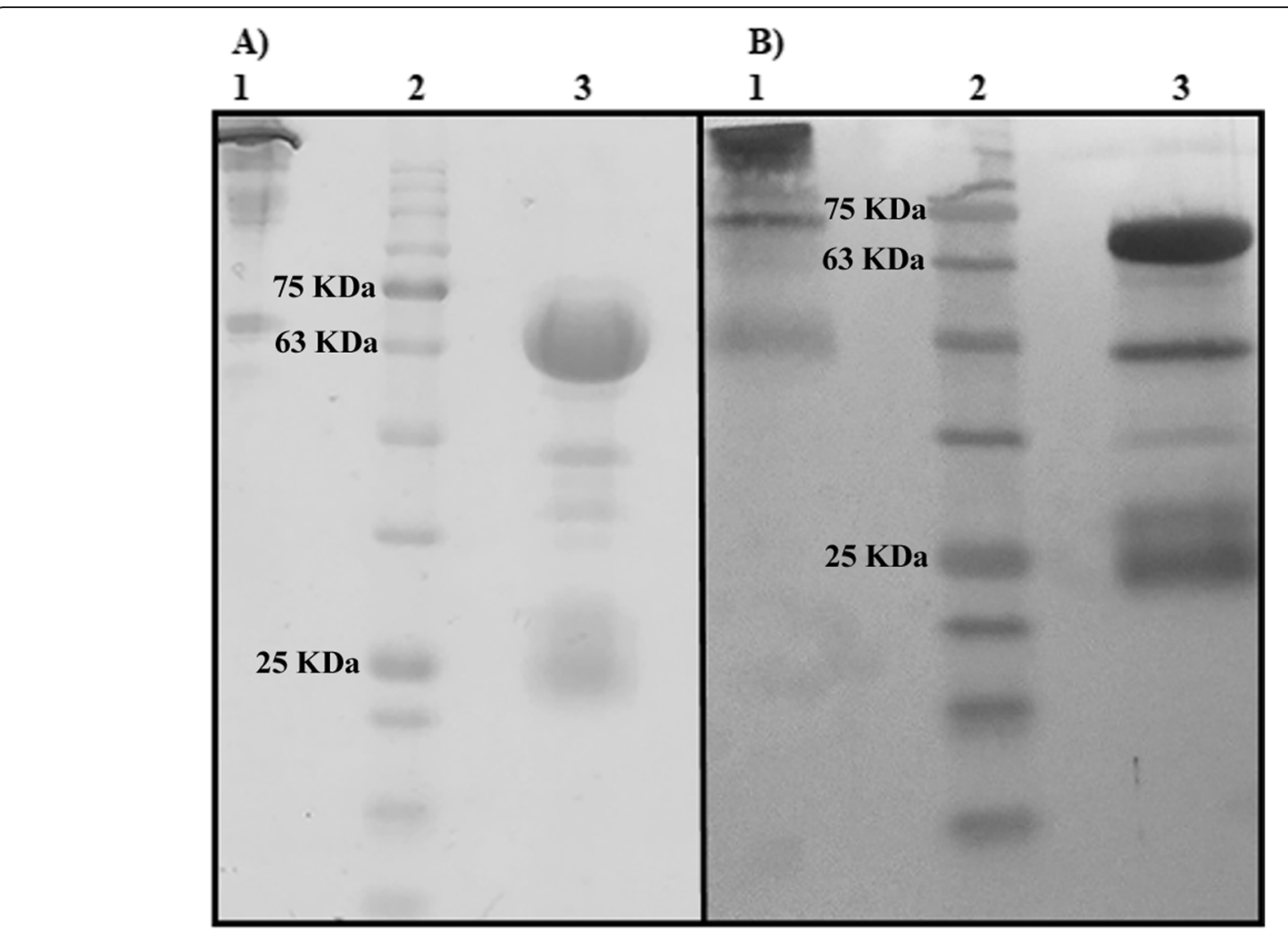

Fig. 2 Analysis of the PEG purified anti-DT IgY. a SDS-PAGE analysis. The IgY samples were resolved on 12\% gel and stained by Coomassie Brilliant Blue R-250. b Western blot analysis. The IgY samples were run on a 12\% SDS-PAGE gel and transferred onto a nitrocellulose membrane. The samples were probed by peroxidase-conjugated rabbit anti-chicken IgY. 1: Non-reducing condition. 2. Molecular weight marker. 3: Reducing condition

Under reducing conditions, it was resolved into 67 and $22 \mathrm{kDa}$ protein bands related to heavy and light chains of the antibody, respectively.

\section{Western blot analysis}

Western blot analysis was performed to confirm the protein bands, which were considered IgY by SDS-PAGE. HRP conjugated anti-chicken IgY reacted strongly with $180 \mathrm{kDa}$ protein band under non-reducing conditions. The conjugated anti-chicken IgY also detected the protein bands of heavy and light chains with 67 and $22 \mathrm{kDa}$ molecular weight under reducing conditions, respectively.

\section{The cytotoxic dose of DT}

The cell viability assay was used to quantify the cytotoxicity of diphtheria toxin. The cytotoxic dose of $99 \%$ of the toxin on Vero cells was calculated about $0.03 \mathrm{ng}$ $(0.13 \mathrm{ng} / \mathrm{ml}$ of culture medium) by taking the highest dilution of DT in which the color of the medium has not been changed. In the control group, the color of the medium was turned to yellow following cell growth.

\section{Neutralization activity of anti-DT $\lg Y$}

In the DT neutralization assay, anti-DT IgY was diluted twofold and was challenged with $10 \mathrm{MCD}$ of the toxin. Neutralization activity of anti-DT IgY was assayed by $\mathrm{pH}$ color change test in the microplate. The lowest quantity of IgY, which neutralized 10 CD99 of the toxin was considered as effective dose 99\% (ED99) and was calculated to be $1.95 \mu \mathrm{g}(8.6 \mu \mathrm{g} / \mathrm{ml}$ of culture medium) of purified IgY. The ED99 value of equine antitoxin (positive control) was determined to be $1.56 \mu \mathrm{g}(6.9 \mu \mathrm{g} / \mathrm{ml}$ of culture medium). In the negative control group, in which toxin was treated with PBS-immunized IgY, cells were not grown, and the color of the medium remained red. In the toxin control group, Vero cells were treated with 10 CD99 of toxin, and the color of the medium remained red, indicating the total cell death.

\section{Discussion}

Diphtheria remains endemic in several developing countries, even following comprehensive vaccination programs [3, 10, 21-23]. Conventional equine diphtheria antitoxin is the current treatment for the neutralization of Diphtheria toxin [6]. However, due 
to limited supplies and the problems related to serum sickness, finding an alternative is highly considerable [8, 10, 24-26].

The IgY enjoys several prominent advantages described previously [11-14]. Several studies are demonstrating the neutralizing effect of egg yolk-derived immunoglobulin (IgY) against different toxins, pathogens, and diseases $[16,27-31]$. However, there is no report of the neutralization effect of IgY on diphtheria toxin to date. In the present study, the chickens were immunized with diphtheria toxoid, and the DT-specific IgY was purified using the PEG precipitation method. The SDS-PAGE analysis of purified IgY showed a purity of about $93 \%$. It was shown that purification of $\operatorname{IgY}$ via PEG precipitation is a preferred method compared to the other purification methods using dextran or chloroform chemicals [32]. Akita and 'Nakai's study demonstrated IgY purity of about $96 \%$ using the PEG purification method [33].. Considering the Akita and Nakai study results, our results show acceptable purity (93\%).

In this study, the neutralizing effect of anti-DT IgY was evaluated against diphtheria toxin using Vero cell viability assay. For potency estimation of antibodies against diphtheria toxin, Vero cell viability assay is approved as an equivalent to Guinea pig in-vivo assay by WHO (WHO 2005) [34]. This assay revealed that the amount of effective dose 99\% (ED99) of anti-DT IgY was $1.95 \mu \mathrm{g}(8.6 \mu \mathrm{g} / \mathrm{ml}$ of culture medium), which would effectively neutralize 10 fold of CD99 of the toxin. This result shows the ability of DT-specific IgY to neutralize the cell toxicity of diphtheria toxin. Considering the amount of ED99, DT-specific IgY shows reasonable and acceptable results of neutralization activity against the cell toxicity of diphtheria toxin in comparison with equine diphtheria antitoxin, $1.56 \mu \mathrm{g}(6.9 \mu \mathrm{g} / \mathrm{ml}$ of culture medium).

Kanchana Usuwanthim et al. developed two murine monoclonal antibodies (mAbs) that could neutralize DT in Vero cell assay. The effective dose of 50\% (ED50) of the mAbs to neutralize 10 Cytotoxic doses 50\% (CD50) of DT (0.084 ng) was $50 \mathrm{ng}$ and $160 \mathrm{ng}$ [35]. Considering that only a portion (\%5-10) of a whole IgY is specific for an antigen and comparing the concepts of CD50 to CD99 as well as ED50 to ED99, our results could be comparable to the results of their study.

In another study, an anti-DT monoclonal antibody was made by Leila M. Sevigny et al. using recombinant technology. They found that $5.5 \mathrm{ng} / \mathrm{ml}$ of this monoclonal antibody $(315 \mathrm{C} 4)$ can achieve total neutralization of DT using a Vero cell-based assay [36]. The protective effect of this monoclonal antibody is very strong and far from other results. Because of insufficient information on their Vero cell assay, we cannot compare the results of anti-DT IgY to their monoclonal antibody. Like other polyclonal antibodies, anti-DT IgY is a mixture of antibodies recognizing different specific epitopes. Moreover, the production of IgY has the advantage of being much more rapid, less expensive, and less technical skill than is required to produce MAbs [37].

\section{Conclusion}

The successful results of our study and also the cost and limited supply of commercial anti-DT antibodies suggest that anti-DT IgY could be used as an alternative antibody against diphtheria toxin. Our findings promote further complimentary evaluation of the neutralization effect of anti-DT IgY under in vivo conditions. Furthermore, this anti-DT IgY may be applicable for in-process and final quality controls in vaccine production as an alternative to equine antibodies.

\section{Methods \\ Diphtheria toxin and toxoid}

Diphtheria toxin (DT) and toxoid (DTx) were obtained from Razi Vaccine and Serum Research Institute (Karaj, Iran), lyophilized to concentrate the proteins, and stored at $-20^{\circ} \mathrm{C}$. The concentrations of samples were determined by the Bradford method [38].

\section{Animals}

The 24-week old laying white leghorn chickens weighing 1200 to $1500 \mathrm{~g}$ were obtained commercially from a local poultry farm (Tehran, Iran), prepared, and kept in individual cages. Chickens had been vaccinated against common poultry diseases and had access to food and water ad libitum. This study was reviewed and approved by the Ethics Committee of the Tehran University of Medical Sciences (No 24271-284541).

\section{Immunization schedule}

A pair of chickens were immunized intramuscularly at 4 sites in the breast muscle with $0.1 \mathrm{mg}$ of diphtheria toxoid in $0.5 \mathrm{ml}$ of phosphate-buffered saline (PBS, pH 7.4), which were emulsified with an equal volume of complete 'Freund's adjuvant (CFA). Another pair of chickens received emulsified PBS with CFA and were used as control. Animals were randomized into the treatment group and control group by the complete randomization method. On days 18, 43 and 62, each chicken received booster injections with incomplete 'Freund's adjuvant (IFA) following the first injection. Eggs were collected daily for 5 months after the first injection and stored at $4{ }^{\circ} \mathrm{C}$ for the next steps. Finally, chickens were sacrificed by $\mathrm{CO}_{2}$ inhalation which was approved by the Ethics Committee of the Tehran University of Medical Sciences. 


\section{Determination of IgY-DTx levels}

An indirect ELISA was used to evaluate the antibody titers of eggs obtained from the immunized chickens. Each experiment was performed in two replicates, and the mean \pm SD of samples was calculated by Excel software 2010. The yolks were separated and diluted (1:5 v/ v) with distilled water, and $\mathrm{pH}$ was adjusted to 5 and incubated overnight at $4{ }^{\circ} \mathrm{C}$. Then samples were centrifuged at $13000 \mathrm{~g}$ for $20 \mathrm{~min}$ at $4{ }^{\circ} \mathrm{C}$, and the supernatant was stored at $-20^{\circ} \mathrm{C}$ as water-soluble fractions (SWFs) [39]. The microplate wells (Nunc) were coated with $100 \mu \mathrm{l}(20 \mu \mathrm{g} / \mathrm{ml})$ of diphtheria toxoid in carbonate/bicarbonate buffer $(0.1 \mathrm{M}, \mathrm{pH}$ : 9.6$)$ overnight at $4{ }^{\circ} \mathrm{C}$. Unbound toxoids were washed with PBS, and non-specific bindings were blocked with $250 \mu \mathrm{l} /$ well of $2.5 \%$ skimmed milk in PBS buffer for $2 \mathrm{~h}$ at room temperature (RT). After washing 3 times with PBS, $100 \mu \mathrm{l}$ of 1:2000 diluted WSF samples (immunized, non-immunized, and PBS) were added to wells and incubated for $2 \mathrm{~h}$ at room temperature. The microplate was washed thoroughly three times with PBS buffer. One hundred $\mu$ of diluted (1:32000) HRP-conjugated rabbit anti-chicken IgY (Sigma) in PBS/Tween 0.1\% (PBST) was added and incubated for $2 \mathrm{~h}$ at room temperature. After washing 4 times with PBST, the color was developed by adding $100 \mu \mathrm{l}$ substrate solution ( $1 \mathrm{mg}$ of Tetramethylbenzidine in $157 \mu \mathrm{l}$ of ethanol, $10 \mathrm{ml} \mathrm{H}_{2} \mathrm{O}, 1 \mathrm{ml}$ of acetate buffer $1.1 \mathrm{M} \mathrm{pH} 5$, and $2 \mu \mathrm{l}$ of $\mathrm{H}_{2} \mathrm{O}_{2}$ ). After $30 \mathrm{~min}$, the reaction was stopped with $\mathrm{HCl} 2 \mathrm{~N}$, and the absorbance of wells was measured at $450 \mathrm{~nm}$.

\section{$\lg Y$ purification}

IgY Polyclonal antibody was purified from immunized 'chicken's egg yolk with PEG method as described previously [40]. Briefly, the yolk was diluted $(1: 3 \mathrm{v} / \mathrm{v})$ with PBS. For precipitation of lipid particles, 3.5\% (w/v) PEG 6000 was added and mixed with a magnetic stirrer for $20 \mathrm{~min}$ at RT. The supernatant containing IgY was isolated by centrifugation $\left(13,000 \mathrm{~g}\right.$ for $20 \mathrm{~min}$ at $\left.4{ }^{\circ} \mathrm{C}\right)$ and filtered through filter paper. Another $8.5 \%(w / v)$ of PEG 6000 was added to the supernatant and mixed for 20 $\mathrm{min}$ at RT. The mixture was then centrifuged $(13,000 \mathrm{~g}$ for $20 \mathrm{~min}$ at $4{ }^{\circ} \mathrm{C}$ ), and the pellet was dissolved in 10 $\mathrm{mL}$ PBS. $12 \%(\mathrm{w} / \mathrm{v})$ of PEG 6000 was added to the solution and mixed for 20 min at RT, followed by centrifugation as above. The resulting pellet was dissolved in $5 \mathrm{ml}$ of PBS, dialyzed overnight against $2 \mathrm{mM}$ phosphate buffer ( $\mathrm{pH}$ 6.5), and finally saved at $-20^{\circ} \mathrm{C}$.

\section{SDS-PAGE and Western blot analysis}

The purity of IgY was evaluated by SDS-PAGE under reducing and non-reducing conditions. SDS-PAGE was carried out in $5 \%$ stacking gel $(1.0 \mathrm{M}$ Tris- $\mathrm{HCl}$ buffer $\mathrm{pH} 6.8)$ and in $12 \%$ separating gel $(1.5 \mathrm{M}$ Tris- $\mathrm{HCl}$ buffer
$\mathrm{pH}$ 8.8) using a vertical slab gel apparatus [41]. IgY samples were treated with sample buffer containing $1 \%$ SDS, $0.001 \%$ bromophenol blue, $50 \mathrm{mM}$ Tris- $\mathrm{HCl}$ (pH 6.8), $1 \% \beta$-mercaptoethanol in reducing conditions, and without $\beta$-mercaptoethanol in non-reducing conditions. Then, samples in reducing conditions were heated for 5 min at $100^{\circ} \mathrm{C}$. After electrophoresis, the gels were stained with Coomassie brilliant blue R250 solution, and destaining steps were performed for visualization of protein bands. The gels were scanned and analyzed via densitometry using ImageJ software (1.48) to calculate the purity of IgY. Verification of IgY was performed by Western blot analysis [42]. Blotting was carried out by transferring the IgY bands from SDS-PAGE gels to the nitrocellulose membrane. The membrane was then blocked with 5\% skimmed milk in PBS for $2 \mathrm{~h}$ at RT. Consequently, the peroxidase-conjugated rabbit antichicken IgY (Sigma,1:4000 dilutions) was added and incubated for another $2 \mathrm{~h}$ at RT. Finally, the protein bands were visualized by freshly prepared 3,3'-Diaminobenzidine $(\mathrm{DAB})$ substrate solution $(9 \mathrm{mg}$ of $\mathrm{DAB}$ and $15 \mu \mathrm{l}$ of $30 \% \mathrm{H}_{2} \mathrm{O}_{2}$ in $20 \mathrm{ml}$ of $50 \mathrm{mM}$ Tris buffer, $\mathrm{pH}$ 7.4). Extensive washing was performed using PBST $(0.1 \%$ Tween in PBS) following each step.

\section{Cell culture}

Vero cells were obtained from Razi Vaccine and Serum Research Institute (Karaj, Iran). The cells were grown in $25 \mathrm{~cm}^{2}$ polystyrene tissue culture flasks with Dulbecco's modified Eagle's minimum essential medium (DMEM) supplemented with $10 \%$ fetal bovine serum (FBS), $1 \%$ penicillin $(10.000 \mathrm{IU} / \mathrm{ml})$ and streptomycin $(10 \mathrm{mg} / \mathrm{ml})$ at $37^{\circ} \mathrm{C}$ in a humidified $\mathrm{CO}_{2}$ incubator. Vero cells were harvested by treating with $1 \mathrm{ml}$ of $0.25 \%$ trypsin in PBS buffer containing $0.1 \%$ ethylenediaminetetraacetic acid (EDTA) and were suspended to a final density of $1 \times 10^{6}$ cells/ml in fresh supplemented DMEM for further cell viability assays [43].

\section{Minimum cytotoxic dose of diphtheria toxin}

DT is a cytotoxic protein for Vero cells. The cell viability assay was performed to quantify DT cytotoxicity using the color change method. Twenty-five $\mu$ l of two-fold serial dilutions of DT were prepared in wells of tissue culture microplate using sterile PBS. Then, $150 \mu \mathrm{l}$ of supplemented DMEM medium and $50 \mu \mathrm{l}$ of Vero cell $\left(5 \times 10^{4}\right.$ cells $)$ were added to each well. The wells without toxin were considered as control. The tissue culture microplate was incubated for $4-5$ days under $5 \% \mathrm{CO}_{2}$ at $37^{\circ} \mathrm{C}$. In the wells in which the toxin inhibited the cellular metabolism, the color of the medium was not changed. The highest dilution of DT, in which the color of media was not changed, has been taken into account for 
the determination of cytotoxic dose of diphtheria toxin, which kills 99\% (CD99) of the cells [44].

\section{Neutralization activity of IgY-DTx}

Neutralizing activities of IgY-DTx against diphtheria toxin were evaluated by the Vero cell viability assay [44]. Twenty-five $\mu \mathrm{l}$ of two-fold serial dilutions of filtersterilized purified IgY were prepared in wells of tissue culture microplate using sterile PBS. Then, $25 \mu \mathrm{l}$ of filter-sterilized DT (10x of CD99) was added to each well and incubated for $60 \mathrm{~min}$ at $37^{\circ} \mathrm{C}$. After toxin neutralization, $125 \mu \mathrm{l}$ of supplemented DMEM medium and $50 \mu \mathrm{l}$ of Vero cell $\left(5 \times 10^{4}\right.$ cells $)$ were added to each well, and finally, the plate was incubated for 4-5 days under $5 \% \mathrm{CO}_{2}$ at $37^{\circ} \mathrm{C}$. The effective dose of $99 \%$ (ED99) of IgY-DTx was calculated by taking the highest dilution of IgY at which the cells were grown, and the color of the medium changed to yellow. Two groups were considered as negative controls, one containing PBS-immunized IgY and the other one containing PBS without any IgY sample. Purified equine immunoglobulins diphtheria antitoxin (Razi vaccine and serum research institute, Karaj, Iran) was used in parallel neutralizing assay and assigned as a positive control.

\section{Abbreviations}

IgY: Immunoglobulin Y; DT: Diphtheria Toxin; DTx: Diphtheria Toxoid; DAT: Diphtheria AntiToxin; ELISA: Enzyme Linked Immuno-Sorbent Assay; PEG: Polyethylene Glycol; SDS-PAGE: Sodium Dodecyl SulphatePolyAcrylamide Gel Electrophoresis; HRP: HorseRadish Peroxidase; CD99: Cytotoxic Dose 99; ED99: Effective Dose 99\%; RF: Rheumatoid Factors; CFA: Complete Freund's Adjuvant; IFA: Incomplete Freund's Adjuvant: WSFs: Water-Soluble Fractions; PBS: Phosphate Buffer Saline; PBST: Phosphate Buffer Saline Tween; DAB: DiAminoBenzidine; DMEM: Dulbecco's Modified Eagle's Minimum; EDTA: EthyleneDiamineTetraacetic Acid; RT: Room Temperature; MCD: Minimum Cytotoxic Dose; FBS: Fetal Bovine Serum; MAbs: Monoclonal AntiBodies

\section{Supplementary Information}

The online version contains supplementary material available at https://doi. org/10.1186/s12896-021-00694-7.

\section{Additional file 1:.}

\section{Acknowledgments}

We kindly acknowledge the Razi vaccine and serum research institute for providing Purified Vero cells, equine immunoglobulins, diphtheria antitoxin, and diphtheria toxin and toxoid.

\begin{abstract}
Authors' contributions
M. RF performed experiments and wrote the manuscript. R. S performed experiments and analyzed data. M. M performed experiments and analyzed data. E. A performed experiments and analyzed data. M. A designed and directed experiments, analyzed data and revised the manuscript. All authors read and approved the final manuscript.
\end{abstract}

\section{Funding}

This work was supported by the Tehran University of Medical Sciences (grant number 24271). It is also declared that the research funding was used to prepare laboratory animals and samples, analysis, and interpretation the data.
Availability of data and materials

The datasets supporting the conclusions of this article are included within the article (and its additional files).

\section{Declarations}

Ethics approval and consent to participate

This study was reviewed and approved by the Ethics Committee of the Tehran University of Medical Sciences (No 24271-284541).

\section{Consent for publication}

Not applicable.

\section{Competing interests}

The authors declare that they have no competing interests.

\section{Author details}

${ }^{1}$ Department of Clinical Biochemistry, School of Medicine, Tehran University of Medical Sciences, Poursina Street, Keshavarz Boulevard, Tehran, Iran. ${ }^{2}$ Department of Clinical Biochemistry, Faculty of Medical Sciences, Tarbiat Modares University, Tehran, Iran. ${ }^{3}$ Department of Biochemistry, School of Medicine, Hamedan University of Medical Science, Hamedan, Iran. ${ }^{4}$ Department of Bacterial Vaccines, Razi Vaccine and Serum Research Institute, Karaj, Iran. ${ }^{5}$ Recombinant Vaccine Research Center, Tehran University of Medical Sciences, Tehran, Iran.

Received: 14 June 2020 Accepted: 27 April 2021

Published online: 12 May 2021

\section{References}

1. Wagner KS, White JM, Lucenko I, Mercer D, Crowcroft NS, Neal S, et al. Diphtheria in the postepidemic period, Europe, 2000-2009. Emerg Infect Dis. 2012;18(2):217-25. https://doi.org/10.3201/eid1802.110987.

2. Murphy JR. Mechanism of diphtheria toxin catalytic domain delivery to the eukaryotic cell cytosol and the cellular factors that directly participate in the process. Toxins. 2011;3(3):294-308. https://doi.org/10.3390/toxins3030294.

3. Mattos-Guaraldi AL, Moreira LO, Damasco PV, Hirata JR. Diphtheria remains a threat to health in the developing world: an overview. Mem Inst Oswaldo Cruz. 2003;98(8):987-93. https://doi.org/10.1590/S0074-02762003000800001.

4. Who 7000. WHO Diphtheria. Updated 08 August 2017; [cited 28 Apr 2018] Available from: https://www.who.int/immunization/monitoring_surveillance/ burden/diphtheria/en/.

5. Bermejo-Martin JF, Avila-Alonso A, González-Rivera M, Tamayo E, Eiros JM, Almansa R. Postbooster antibodies from humans as source of diphtheria antitoxin. Emerg Infect Dis. 2016;22(7):1265-7. https://doi.org/10.3201/eid22 07.151670 .

6. Wagner K, Stickings P, White J, Neal S, Crowcroft N, Sesardic D, et al. A review of the international issues surrounding the availability and demand for diphtheria antitoxin for therapeutic use. Vaccine. 2009;28(1):14-20. https://doi.org/10.1016/j.vaccine.2009.09.094.

7. Olender A. Antibiotic resistance and detection of the most common mechanism of resistance (MLSB) of opportunistic Corynebacterium. Chemotherapy. 2013;59(4):294-306. https://doi.org/10.1159/000357467.

8. Robert J. Serum Sickness. J Cutaneous Med Surg. 2000;4(4):223-5.

9. Bissumbhar B, Rakhmanova A, Berbers G, lakolev A, Nosikova E, Melnick O, et al. Evaluation of diphtheria convalescent patients to serve as donors for the production of anti-diphtheria immunoglobulin preparations. Vaccine. 2004;22(15-16):1886-91.

10. Both L, White J, Mandal S, Efstratiou A. Access to diphtheria antitoxin for therapy and diagnostics. Eurosurveillance. 2014;19(24):20830.

11. Larsson A, R-M B, Lindahl T, P-O F. Chicken antibodies: taking advantage of evolution-a review. Poult Sci. 1993;72(10):1807-12. https://doi.org/10.3382/ ps.0721807.

12. Malmarugan S, Raman $M$, Jaisree $S$, Elanthalir P. Egg immunoglobulins-an alternative source of antibody for diagnosis of infectious bursal disease. Veterinarski Arhiv. 2005;75(1):49-56.

13. Larsson A, Wejåker P-E, Forsberg P-O, Lindahl T. Chicken antibodies: a tool to avoid interference by complement activation in ELISA.J Immunol Methods. 1992;156(1):79-83. https://doi.org/10.1016/0022-1759(92)90013-J. 
14. Larsson A, Karlsson-Parra A, Sjöquist J. Use of chicken antibodies in enzyme immunoassays to avoid interference by rheumatoid factors. Clin Chem. 1991;37(3):411-4. https://doi.org/10.1093/clinchem/37.3.411.

15. Dávalos-Pantoja L, Ortega-Vinuesa JL, Bastos-González D, Hidalgo-Alvarez R. A comparative study between the adsorption of lgY and lgG on latex particles. J Biomat Sci Polymer Ed. 2000;11(6):657-73. https://doi.org/10.11 $63 / 156856200743931$.

16. Kovacs-Nolan J, Mine Y. Egg yolk antibodies for passive immunity. Annu Rev Food Sci Technol. 2012;3(1):163-82. https://doi.org/10.1146/annurev-food022811-101137.

17. Schade R, Terzolo H. IgY-technology: application and trends. Personal Communication 2006.

18. Thu HM, Myat TW, Win MM, Thant KZ, Rahman S, Umeda K, et al. Chicken egg yolk antibodies (igy) for prophylaxis and treatment of rotavirus diarrhea in human and animal neonates: a concise review. Korean J Food Sci Anim Resour. 2017;37(1):1-9. https://doi.org/10.5851/kosfa.2017.37.1.1.

19. Rahman S, Van Nguyen S, Icatlo FC Jr, Umeda K, Kodama Y. Oral passive IgY-based immunotherapeutics: a novel solution for prevention and treatment of alimentary tract diseases. Hum Vacc Immunother. 2013;9(5): 1039-48. https://doi.org/10.4161/hv.23383.

20. Feng Y, Liu W, Shi D. Effectiveness of egg yolk antibody against Shiga toxin II variant toxicity in vitro and in vivo. Curr Microbiol. 2013;67(4):448-53. https://doi.org/10.1007/s00284-013-0384-8.

21. Vitek CR, Wharton M. Diphtheria in the former Soviet Union: reemergence of a pandemic disease. Emerg Infect Dis. 1998;4(4):539-50. https://doi.org/1 0.3201/eid0404.980404

22. Dittmann S. Epidemic Diptheria in the newly independent states of the former USSR_-situation and lessons learned. Biologicals. 1997;25(2):179-86. https://doi.org/10.1006/biol.1997.0081.

23. Jain A, Samdani S, Meena $V$, Sharma MP. Diphtheria: it is still prevalent!!! Int J Pediatr Otorhinolaryngol. 2016;86:68-71. https://doi.org/10.1016/j.ijporl.201 6.04.024.

24. Bonnet J, Begg N. Control of diphtheria: guidance for consultants in communicable disease control. Commun Dis Public Health. 1999:2(4):242-9.

25. Stiehm ER. Adverse effects of human immunoglobulin therapy. Transfus Med Rev. 2013;27(3):171-8. https://doi.org/10.1016/j.tmrv.2013.05.004.

26. Cherin P, Marie I, Michallet M, Pelus E, Dantal J, Crave J-C, et al. Management of adverse events in the treatment of patients with immunoglobulin therapy: a review of evidence. Autoimmun Rev. 2016;15(1): 71-81. https://doi.org/10.1016/j.autrev.2015.09.002.

27. Solhi $R$, Alebouyeh $M$, Khafri $A$, Rezaeifard $M$, Aminian M. In vitro evaluation of cross-strain inhibitory effects of lgY polyclonal antibody against $\mathrm{H}$. pylori. Microb Pathog. 2017;110:682-7. https://doi.org/10.1016/j.micpath.2017.03.02 5.

28. Araújo A, Lobato Z, Chávez-Olórtegui C, Velarde D. Brazilian IgY-Bothrops antivenom: studies on the development of a process in chicken egg yolk. Toxicon. 2010;55(4):739-44. https://doi.org/10.1016/j.toxicon.2009.11.004.

29. Zhen Y-H, Jin L-J, Guo J, Li X-Y, Lu Y-N, Chen J, et al. Characterization of specific egg yolk immunoglobulin (lgY) against mastitis-causing Escherichia coli. Vet Microbiol. 2008;130(1-2):126-33. https://doi.org/10.1016/j.vetmic.2 007.12.014.

30. Hong KS, Ki M-R, Ullah HMA, Lee E-J, Kim YD, Chung M-J, et al. Preventive effect of anti-VacA egg yolk immunoglobulin (lgY) on helicobacter pyloriinfected mice. Vaccine. 2018;36(3):371-80. https://doi.org/10.1016/j.vaccine.2 017.11.082.

31. Sudjarwo SA, Eraiko K, Wardani G, Sudjarwo K. The potency of chicken egg yolk immunoglobulin (lgY) specific as immunotherapy to Mycobacterium tuberculosis infection. J Adv Pharmaceut Technol Res. 2017:8(3):91.

32. Bizhanov G, Vyshniauskis $G$. A comparison of three methods for extracting IgY from the egg yolk of hens immunized with Sendai virus. Vet Res Commun. 2000;24(2):103-13. https://doi.org/10.1023/A:1006460506303.

33. Akita EM, Nakai S. Comparison of four purification methods for the production of immunoglobulins from eggs laid by hens immunized with an enterotoxigenic E. coli strain. J Immunol Methods. 1993;160(2):207-14. https://doi.org/10.1016/0022-1759(93)90179-B.

34. Organization WHO. Recommendations for diphtheria, tetanus, pertussis and combined vaccines (amendments 2003). WHO Expert Committee on Biological Standardization Fifty-fourth report. Geneva: World Health Organization; 2005
35. Usuwanthim K, Pootong A, Chaisri U, Tongtawe P, Tapchaisri P, ChongsaNguan $\mathrm{M}$, et al. Murine monoclonal antibodies neutral-izing the cytotoxic activity of diphtheria toxin. Asian Pac J Allergy Immunol. 2008;26(1):47-55

36. Sevigny LM, Booth BJ, Rowley KJ, Leav BA, Cheslock PS, Garrity KA, et al. Identification of a human monoclonal antibody to replace equine diphtheria antitoxin for treatment of diphtheria intoxication. Infect Immun. 2013;81(11):3992-4000. https://doi.org/10.1128/IAl.00462-13.

37. Lipman NS, Jackson LR, Trudel LJ, Weis-Garcia F. Monoclonal versus polyclonal antibodies: distinguishing characteristics, applications, and information resources. ILAR J. 2005;46(3):258-68. https://doi.org/10.1093/ila r.46.3.258

38. Aminian M, Nabatchian F, Vaisi-Raygani A, Torabi M. Mechanism of Coomassie brilliant blue G-250 binding to cetyltrimethylammonium bromide: an interference with the Bradford assay. Anal Biochem. 2013; 434(2):287-91. https://doi.org/10.1016/j.ab.2012.11.014.

39. Akita $E$, Nakai S. Immunoglobulins from egg yolk: isolation and purification. J Food Sci. 1992;57(3):629-34. https://doi.org/10.1111/j.1365-2621.1992. tb08058.x.

40. Polson A, Coetzer T, Kruger J, Von Maltzahn E, Van der Merwe K. Improvements in the isolation of lgY from the yolks of eggs laid by immunized hens. Immunol Investig. 1985;14(4):323-7. https://doi.org/10.31 09/08820138509022667.

41. Laemmli UK. Cleavage of structural proteins during the assembly of the head of bacteriophage T4. Nature. 1970;227(5259):680.

42. Towbin H, Staehelin T, Gordon J. Electrophoretic transfer of proteins from polyacrylamide gels to nitrocellulose sheets: procedure and some applications. Proc Natl Acad Sci. 1979;76(9):4350-4. https://doi.org/10.1073/ pnas.76.9.4350.

43. Aggerbeck $\mathrm{H}$, Heron I. Improvement of a Vero cell assay to determine diphtheria antitoxin content in sera. Biologicals. 1991;19(2):71-6. https://doi. org/10.1016/1045-1056(91)90002-2.

44. Miyamura K, Nishio S, Ito A, Murata R, Kono R. Micro cell culture method for determination of diphtheria toxin and antitoxin titres using VERO cells: I. studies on factors affecting the toxin and antitoxin titration. J Biol Stand 1974;2(3):189-201. https://doi.org/10.1016/0092-1157(74)90015-8.

\section{Publisher's Note}

Springer Nature remains neutral with regard to jurisdictional claims in published maps and institutional affiliations.

Ready to submit your research? Choose BMC and benefit from:

- fast, convenient online submission

- thorough peer review by experienced researchers in your field

- rapid publication on acceptance

- support for research data, including large and complex data types

- gold Open Access which fosters wider collaboration and increased citations

- maximum visibility for your research: over $100 \mathrm{M}$ website views per year

At BMC, research is always in progress.

Learn more biomedcentral.com/submission 